\title{
A Simple and Highly Sensitive Turn-on Schiff Base Type Naked-eye Fluorescent Sensor for Aluminum Ion in Living Cells
}

\author{
Sedat Keskin and Mevlut Bayrakci* \\ Karamanoglu Mehmetbey University, Faculty of Engineering, Department of Bioengineering 70200, \\ Karaman/TURKEY \\ *Corresponding author: E-mail: mevlutbayrakci@gmail.com \\ Tel.: +903382262200 fax: +903382262214
}

Received: 09-28-2018

\begin{abstract}
Six different Schiff bases to be used as turn-on fluorescent probes based on photoinduced electron transfer (PET) mechanism for the recognition of aluminum ions were successfully synthesized and characterized. The binding abilities of synthesized compounds with different metal cations were investigated by absorption and emission spectra. From the spectrophotometric experiments, it were seen that compound SK-1 displayed an excellent fluorescence response towards targeted aluminum ions probably due to its suitable chelating structure. Furthermore, such compound SK-1 also showed high sensitivity and selectivity response towards aluminum ions over other competing ions. In addition, the potential biological applications of SK-1 to detect aluminum ions in living cells were also investigated and results showed that fluorescence sensor SK-1 could be a promising probe for determining and/or monitoring aluminum ions in both biological and/or chemical samples.
\end{abstract}

Keywords: Schiff Base, fluorescent probe, cell imaging, aluminum, PET.

\section{Introduction}

Aluminum is one of the most abundant metal elements in the Earth's crust and has an important place in our live. ${ }^{1}$ Due to different reasons such as both ecological system and human activities, high quantities of aluminum are found in the environment. ${ }^{2}$ The presence of excess amount of aluminum in nature life affects the living beings. Consequently, some natural products containing large amount of aluminum in food chain are slowly consumed by human beings and this consumption causes many toxic effects towards human health and this toxicity leads to different diseases such as cancer, neurotoxicity, dialysis disease, Alzheimer's and Parkinson's diseases. ${ }^{3-6}$ With respect to the World Health Organization, desired concentration of aluminum in drinking water must be limited to $7.4 \mu \mathrm{M}^{7}$ Therefore, it is important topic to design and develop effective analytical methods or instruments for detection of aluminum ions in environmental and/or biological systems. Although many different and sophisticated analytical techniques including inductively coupled plasma emission (ICP-OES) or mass spectrome- try (ICP-MS), and atomic absorption spectrometry have been used extensively for the detection of aluminum ions, ${ }^{8,9}$ most of these techniques have some disadvantages such as time consuming, qualified personal and high cost. ${ }^{10}$ But among them, fluorescence spectroscopy is most popular analytical instrument for the detection of metal ions and it is preferred intensively by scientists in analytical applications owing to its easy operation, comparatively low cost, and high sensitivity, etc. ${ }^{11}$ Thus, many different fluorescence based chemosensors specific for metal ions have been designed and developed. Compared to these metal ions, just a few fluorescent probes have been reported for detection of trace amount of aluminum ions. Some limitations such as poor coordination ability and lack of spectroscopic characteristics have always been problematic for the detection of aluminum ions. ${ }^{12}$ In addition to these limitations, both complicated synthesis and solubility properties of new fluorescent probes are also other restrictions in the point of design of aluminum sensors. ${ }^{13}$ Therefore, it is necessary and important to design and synthesis of aluminum sensors that can be easily prepared and dissolved. Many sensitive and selective fluorescent sensors 
for metal cations have been reported based on fluorescence resonance energy transfer (FRET) ${ }^{14}$ chelation- enhanced fluorescence (CHEF), ${ }^{15}$ internal charge transfer (ICT), ${ }^{16}$ photoinduced electron transfer (PET), ${ }^{17}$ and excimer/exciplex formation mechanisms. ${ }^{18}$ However, although photoinduced electron transfer (PET)-based fluorogenic sensors have many advantages, ${ }^{19}$ their synthesis and application are not common in the literature. Although there are very interesting literature reports about photoinduced electron transfer (PET)-based fluorogenic sensors for different analytes, ${ }^{20-22}$ synthesis of Schiff base type probes are very inspirational owing to their easily preparation, faster response and high selectivity towards specific analytes of interest. Schiff bases are the most popular class of synthetic compounds in organic, medicinal and pharmaceutical chemistry due to their unique biochemical properties such as antitumor, anti-HIV, antibacterial, antioxidant, anti-inflammatory, antifungal, pesticidal, anthelmintic and antihypertensive, activitie. ${ }^{23-25}$ Although, there are appropriate literature reports showing their biological applications of Schiff base compounds, recently, limited number of literature results about using of Schiff base derivatives as fluorescent probe for the detection of metal ions in living cell have been existed. ${ }^{26-30}$ In the light of these literature, here, we presented the design, synthesis and biological applications of a series of Schiff base based fluorescent sensors containing ortho, meta and para hydroxy units which could detect aluminum ions by the 'naked eye.

\section{Experimental}

\section{1. General}

2,3-dihydroxybenzaldehyde, 3,4-dihydroxybenzaldehyde, ortho, meta and para aminophenol and all metal salts were of analytical grade and purchased from Sigma-Aldrich or Merck and was further used without any purification. ${ }^{1} \mathrm{H}$ NMR spectra was recorded on Agilent Premium Compact spectrometer operating at $600 \mathrm{MHz}$. Chemical shifts were reported as $\delta$ values (ppm). Peak multiplicities were expressed as follows: s, singlet; bs, broad singlet; $\mathrm{d}$, doublet; $\mathrm{t}$, triplet and $\mathrm{m}$, multiplet. Bruker Vertex FT-IR spectrometer (ATR) was used for FT-IR spectra. UV-vis absorbance spectra were collected by a Shimadzu UV-1800 and the fluorescence measurements were obtained by Hitachi F-7100.

\section{2. General Procedure for the Synthesis of Schiff Base Probes}

To a stirred solution of corresponding ortho, meta or para aminophenol compounds $(1.5 \mathrm{mmol})$ in $20 \mathrm{~mL}$ absolute ethanol was added $1.5 \mathrm{mmol}$ of 2,3-dihydroxybenzaldehyde (for SK-1, SK-2 and SK-3, respectively) or $1.5 \mathrm{mmol}$ of 3,4-dihydroxybenzaldehyde (for MK-2, MK-3 and MK4, respectively); the reaction mixture was stirred under reflux for $18 \mathrm{~h}$. After completion of the reaction, excess amount of solvent was removed under reduced pressure and the solid residue was washed with $1 \mathrm{~N} \mathrm{HCl}$, brine and excess amount of water. The crude product was crystallized from $\mathrm{CH}_{2} \mathrm{Cl}_{2}-\mathrm{C}_{2} \mathrm{H}_{5} \mathrm{OH}$ (1:1) solvent system (Scheme 1).

SK-1: Red solid with 68\% yields, FT-IR $\left(\right.$ ATR $\left.\mathrm{cm}^{-1}\right): 1616$ (C=N stretching). ${ }^{1} \mathrm{H}$ NMR (600 MHz DMSO): $\delta 14.21$ (bs, 1H, OH) 9.88 (bs, 1H, OH), $9.02(\mathrm{bs}, 1 \mathrm{H}, \mathrm{OH}), 8.91$ (s, $1 \mathrm{H}, \mathrm{CH}=\mathrm{N}), 7.38(\mathrm{~d}, J=8.3 \mathrm{~Hz}, 1 \mathrm{H}, \operatorname{Ar}-\mathrm{H}), 7.10(\mathrm{~m}, 1 \mathrm{H}$, Ar-H), $7.02(\mathrm{~m}, 1 \mathrm{H}, \mathrm{Ar}-\mathrm{H}), 6.95(\mathrm{~m}, 1 \mathrm{H}, \mathrm{Ar}-\mathrm{H}), 6.87(\mathrm{~m}$, $1 \mathrm{H}, \mathrm{Ar}-\mathrm{H}), 6.77(\mathrm{~m}, 1 \mathrm{H}, \mathrm{Ar}-\mathrm{H}), 6.69(\mathrm{~m}, 1 \mathrm{H}, \mathrm{Ar}-\mathrm{H})$. Anal. calcd. For $\mathrm{C}_{13} \mathrm{H}_{11} \mathrm{O}_{3} \mathrm{~N}$ : C, 68.11; H, 4.84; N, 6.11. Found: C, $68.09 ; \mathrm{H}, 4.90 ; \mathrm{N}, 6.19 \%$.

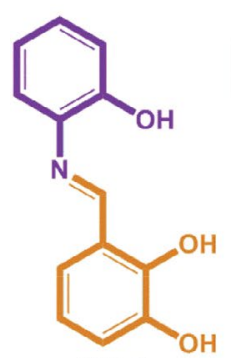

SK-1

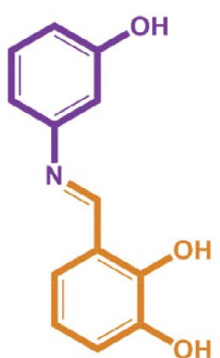

SK-2

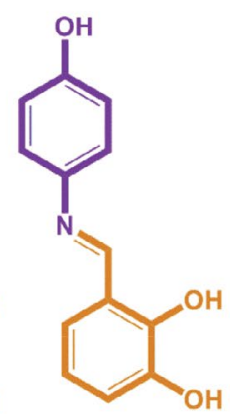

SK-3

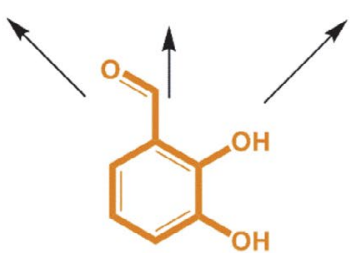<smiles>Oc1ccc(/C=N/c2ccccc2O)cc1O</smiles><smiles>Oc1cccc(/N=C/c2ccc(O)c(O)c2)c1</smiles><smiles>CNc1ccc(O)cc1</smiles>

MK-2

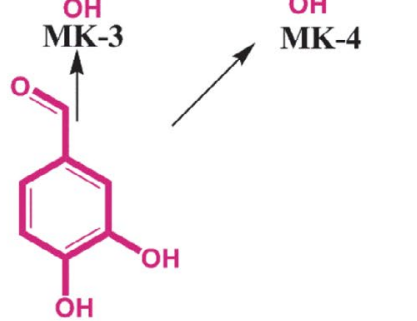

Scheme 1. The synthetic route of Schiff base compounds (SK-1, SK-2, SK-3, MK-2, MK-3, and MK-4) 
SK-2: Dark red solid with 70\% yields, FT-IR $\left(\right.$ ATR $\left.\mathrm{cm}^{-1}\right)$ : 1623 (C=N stretching). ${ }^{1} \mathrm{H}$ NMR (600 MHz DMSO): $\delta$ 14.18 (bs, $1 \mathrm{H}, \mathrm{OH}) 9.87$ (bs, $1 \mathrm{H}, \mathrm{OH}), 9.03$ (bs, $1 \mathrm{H}, \mathrm{OH}$ ), $8.89(\mathrm{~s}, 1 \mathrm{H}, \mathrm{CH}=\mathrm{N}), 7.35(\mathrm{~d}, J=8.4 \mathrm{~Hz}, 1 \mathrm{H}, \mathrm{Ar}-\mathrm{H}), 7.13$ (m, 1H, Ar-H), $7.03(\mathrm{~m}, 1 \mathrm{H}, \mathrm{Ar}-\mathrm{H}), 6.92(\mathrm{~m}, 1 \mathrm{H}, \mathrm{Ar}-\mathrm{H})$, $6.85(\mathrm{~m}, 1 \mathrm{H}, \mathrm{Ar}-\mathrm{H}), 6.74(\mathrm{~m}, 1 \mathrm{H}, \mathrm{Ar}-\mathrm{H}), 6.65(\mathrm{~s}, 1 \mathrm{H}, \mathrm{Ar}-$ H). Anal. calcd. For $\mathrm{C}_{13} \mathrm{H}_{11} \mathrm{O}_{3} \mathrm{~N}$ : C, 68.11; H, 4.84; N, 6.11. Found: C, 68.03; H, 4.80; N, 6.07\%.

SK-3: Dark red solid with $70 \%$ yields, FT-IR $\left(\right.$ ATR $\left.\mathrm{cm}^{-1}\right)$ : 1621 (C=N stretching). ${ }^{1} \mathrm{H}$ NMR (600 MHz DMSO): $\delta$ 14.17 (bs, 1H, OH) 9.88 (bs, 1H, OH), 9.06 (bs, 1H, OH), $8.91(\mathrm{~s}, 1 \mathrm{H}, \mathrm{CH}=\mathrm{N}), 7.34(\mathrm{~d}, J=8.4 \mathrm{~Hz}, 1 \mathrm{H}, \mathrm{Ar}-\mathrm{H}), 7.17-$ $7.11(\mathrm{~m}, 3 \mathrm{H}, \mathrm{Ar}-\mathrm{H}), 6.83(\mathrm{~m}, 1 \mathrm{H}, \mathrm{Ar}-\mathrm{H}), 6.34(\mathrm{~m}, 1 \mathrm{H}, \mathrm{Ar}-$ $\mathrm{H}), 6.21(\mathrm{~m}, 1 \mathrm{H}, \mathrm{Ar}-\mathrm{H})$. Anal. calcd. For $\mathrm{C}_{13} \mathrm{H}_{11} \mathrm{O}_{3} \mathrm{~N}$ : C, $68.11 ; \mathrm{H}, 4.84 ; \mathrm{N}, 6.11$. Found: C, 68.03; H, 4.88; N, 6.15\%.

MK-2: Red solid with 71\% yields, FT-IR $\left(\right.$ ATR cm $\left.{ }^{-1}\right): 1635$ (C=N stretching). ${ }^{1} \mathrm{H}$ NMR (600 MHz DMSO): $\delta 9.84$ (bs, $1 \mathrm{H}, \mathrm{OH}) 9.48$ (bs, 1H, OH), $9.03(\mathrm{bs}, 1 \mathrm{H}, \mathrm{OH}), 8.87(\mathrm{~s}, 1 \mathrm{H}$, $\mathrm{CH}=\mathrm{N}), 7.27(\mathrm{~m}, 2 \mathrm{H}, \mathrm{Ar}-\mathrm{H}), 7.18(\mathrm{~m}, 2 \mathrm{H}, \mathrm{Ar}-\mathrm{H}), 7.10-$ $7.04(\mathrm{~m}, 3 \mathrm{H}, \mathrm{Ar}-\mathrm{H})$. Anal. calcd. For $\mathrm{C}_{13} \mathrm{H}_{11} \mathrm{O}_{3} \mathrm{~N}$ : C, 68.11; $\mathrm{H}, 4.84$; N, 6.11. Found: C, 68.09; H, 4.90; N, 6.19\%.

MK-3: Red solid with 65\% yields, FT-IR $\left(\right.$ ATR $\left.\mathrm{cm}^{-1}\right)$ : 1634 (C=N stretching). ${ }^{1} \mathrm{H}$ NMR (600 MHz DMSO): $\delta 9.81$ (bs, $1 \mathrm{H}, \mathrm{OH}) 9.52(\mathrm{bs}, 1 \mathrm{H}, \mathrm{OH}), 9.11(\mathrm{bs}, 1 \mathrm{H}, \mathrm{OH}), 8.91(\mathrm{~s}, 1 \mathrm{H}$, $\mathrm{CH}=\mathrm{N}), 7.33(\mathrm{~m}, 2 \mathrm{H}, \mathrm{Ar}-\mathrm{H}), 7.25(\mathrm{~m}, 1 \mathrm{H}, \mathrm{Ar}-\mathrm{H}), 7.09(\mathrm{~m}$, $1 \mathrm{H}, \mathrm{Ar}-\mathrm{H}), 6.88(\mathrm{~m}, 2 \mathrm{H}, \mathrm{Ar}-\mathrm{H}), 6.57(\mathrm{~m}, 1 \mathrm{H}, \mathrm{Ar}-\mathrm{H})$. Anal. calcd. For $\mathrm{C}_{13} \mathrm{H}_{11} \mathrm{O}_{3} \mathrm{~N}$ : C, 68.11; $\mathrm{H}, 4.84 ; \mathrm{N}, 6.11$. Found: C, $68.03 ; \mathrm{H}, 4.80 ; \mathrm{N}, 6.07 \%$.

MK-4: Dark red solid with 58\% yields, FT-IR $\left(\right.$ ATR $\left.\mathrm{cm}^{-1}\right)$ : 1620 (C=N stretching). ${ }^{1} \mathrm{H}$ NMR (600 MHz DMSO): $\delta$
9.81 (bs, 1H, OH) 9.47 (bs, 1H, OH), 9.16 (bs, $1 \mathrm{H}, \mathrm{OH}$ ), $8.90(\mathrm{~s}, 1 \mathrm{H}, \mathrm{CH}=\mathrm{N}), 7.34-7.29(\mathrm{~m}, 2 \mathrm{H}, \mathrm{Ar}-\mathrm{H}), 7.17(\mathrm{~m}$, $2 \mathrm{H}$, Ar-H), $7.03(\mathrm{~m}, 3 \mathrm{H}$, Ar- $\mathrm{H})$. Anal. calcd. For $\mathrm{C}_{13} \mathrm{H}_{11} \mathrm{O}_{3} \mathrm{~N}$ : C, 68.11; H, 4.84; N, 6.11. Found: C, 68.03; H, $4.88 ; \mathrm{N}, 6.15 \%$.

\section{3. Uv-Vis and Fluorescence Studies}

The stock solutions of SK-1, SK-2, SK-3, MK-2, MK-3 and MK-4 (1 mM), the guest nitrate salts of metal cations $\left(\mathrm{Li}^{+}, \mathrm{Na}^{+}, \mathrm{Ag}^{+}, \mathrm{Ca}^{2+}, \mathrm{Ba}^{2+}, \mathrm{Co}^{2+}, \mathrm{Cs}^{+}, \mathrm{Cu}^{2+}, \mathrm{Mg}^{2+}\right.$, $\mathrm{Hg}^{2+}, \mathrm{Mn}^{2+}, \mathrm{Pb}^{2+}, \mathrm{Ni}^{2+}, \mathrm{Sr}^{2+}, \mathrm{Zn}^{2+}$ and $\left.\mathrm{Al}^{3+}\right)(1 \mathrm{mM})$ in DMF were prepared. In absorption and emission experiments, the volume of studied solutions was adjusted as 2.0 $\mathrm{mL}$. Titration experiments were performed by addition of corresponding amount of metal cation solutions to a DMF solution of targeted fluorescent probe (SK-1). The absorption spectra of SK-1, SK-2, SK-3, MK-2, MK-3 and MK-4 in the presence and absence of metal cations were recorded in the range of $200-600 \mathrm{~nm}$. All emission spectra were obtained at room temperature under the excitation of $400-430 \mathrm{~nm}$. The solutions were scanned $(1200 \mathrm{~nm} / \mathrm{min})$ with 400 watt of PMT voltage in a spectrofluorometer with the range of $400-750 \mathrm{~nm}$. The widths of the slit for the both excitation and emission were adjusted at $5 \mathrm{~nm}$. The best fluorescence intensity at $530 \mathrm{~nm}$ was determined under the excitation at the wavelength of $430 \mathrm{~nm}$.

\section{4. Biological Applications}

The living MCF7 cells were provided by ATCC (American Type Culture Collection, Rockville, MD, USA). MCF7 cells were incubated with $10 \mu \mathrm{M}$ of $\mathrm{Al}^{3+}$ ions in the culture medium at $37{ }^{\circ} \mathrm{C}$ for $1 \mathrm{~h}$ and washed with phos-
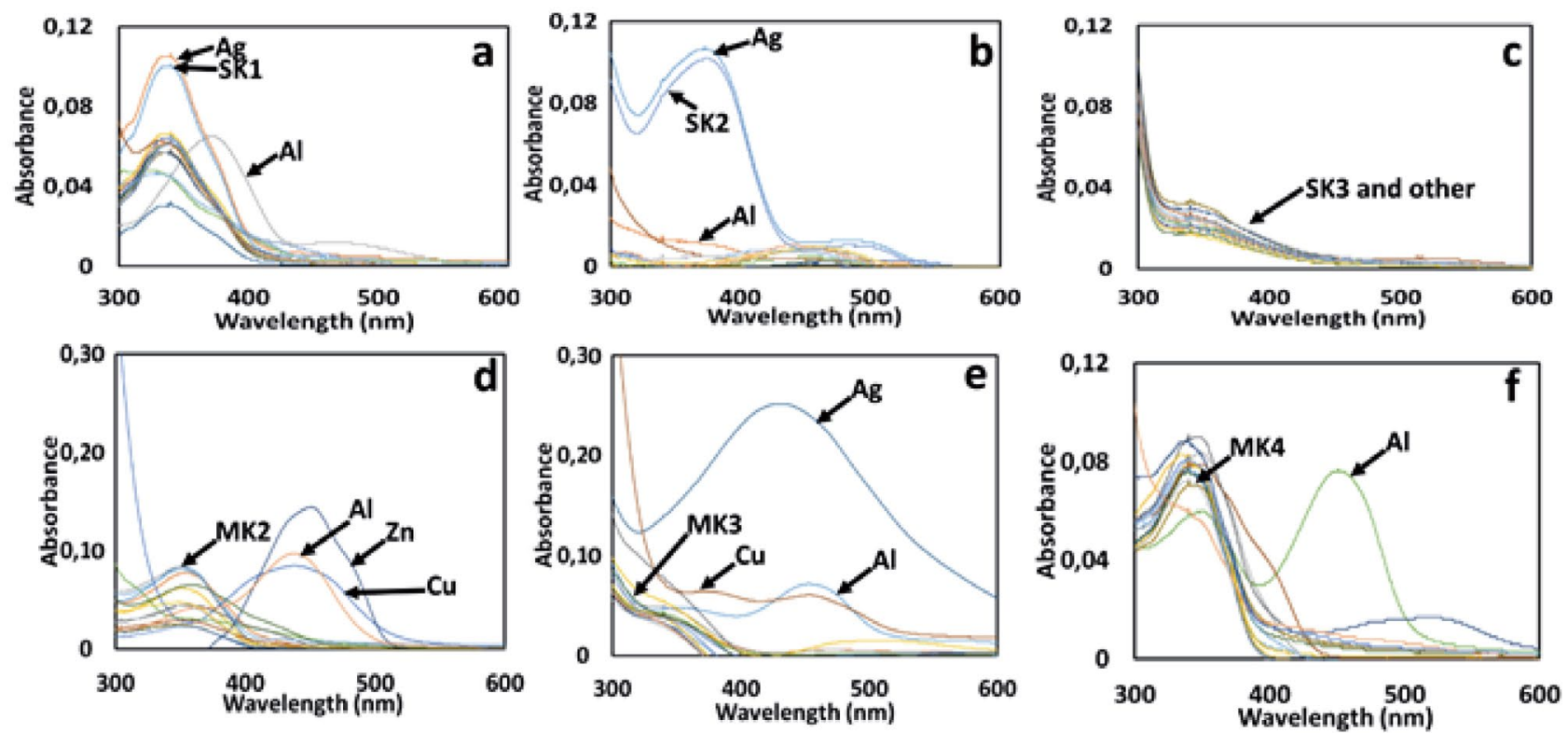

Fig. 1. UV-vis absorption spectra of $(1 \mu \mathrm{M})$; (a) SK-1, (b) SK-2, (c) SK-3, (d) MK-2, (e) MK-3, and (f) MK-4 in the presence of several metal ions such as $\mathrm{Li}^{+}, \mathrm{Na}^{+}, \mathrm{Ag}^{+}, \mathrm{Ca}^{2+}, \mathrm{Ba}^{2+}, \mathrm{Co}^{2+}, \mathrm{Cs}^{+}, \mathrm{Cu}^{2+}, \mathrm{Mg}^{2+}, \mathrm{Hg}^{2+}, \mathrm{Mn}^{2+}, \mathrm{Pb}^{2+}, \mathrm{Ni}^{2+}, \mathrm{Sr}^{2+}, \mathrm{Zn}^{2+}$ and $\mathrm{Al}^{3+}$ (10 eq. for each metal ion). 
phate buffered saline (PBS) followed by the addition of 10 $\mu \mathrm{M}$ of SK-1. Bright field and fluorescent images were taken from Leica DM3000 fluorescence microscopy.

\section{Results and Discussion}

\section{1. UV-vis Absorption Studies}

The absorption spectrum of the Schiff bases SK-1, SK-2, SK-3, MK-2, MK-3 and MK-4 was investigated by the absence and/or presence of 10 equiv. of metal cations such as $\mathrm{Li}^{+}, \mathrm{Na}^{+}, \mathrm{Ag}^{+}, \mathrm{Ca}^{2+}, \mathrm{Ba}^{2+}, \mathrm{Co}^{2+}, \mathrm{Cs}^{+}, \mathrm{Cu}^{2+}, \mathrm{Mg}^{2+}$, $\mathrm{Hg}^{2+}, \mathrm{Mn}^{2+}, \mathrm{Pb}^{2+}, \mathrm{Ni}^{2+}, \mathrm{Sr}^{2+}, \mathrm{Zn}^{2+}$ and $\mathrm{Al}^{3+}$. As seen in Fig. 1 , the absorption spectrum of all Schiff bases, exhibited a broad absorption band attributable to $\pi-\pi^{*}$ transition of the imine moiety at around $342 \mathrm{~nm}$. The absorption band positions generally remained unchanged over the various metal ions except $\mathrm{Al}^{3+}$ ions. After the addition of $\mathrm{Al}^{3+}$, the appreciable bathochromic or hypochromic changes at around $342 \mathrm{~nm}$ for SK-1, SK-2, MK-2, MK-3 and MK-4 was observed owing to the imine nitrogen $(\mathrm{CH}=\mathrm{N})$ was involved in coordination with $\mathrm{Al}^{3+}$ ion. However, considerable changes in the absorption spectra of the SK-3 was not observed over the various metal ions (Fig. 1c). Furthermore, new absorption bands at around $470 \mathrm{~nm}$ (for SK-1, and SK-2) and $450 \mathrm{~nm}$ (for MK-2, MK-3 and MK4) were seen probably due to the complexation capabilities of these molecules with $\mathrm{Al}^{3+}$ ions. Since absorption spectroscopy is a complementary part of emission spectroscopy, fluorescence emission studies were also applied for the getting more information about the spectrophotometric results.

\section{2. Fluorescence Emission Analysis}

High selectivity is necessary to define the excellent chemosensor. Therefore, to evidence the usability of the synthesized Schiff bases as a selective sensor, the fluorescence behavior of Schiff bases SK-1, SK-2, SK-3, MK-2, MK-3 and MK-4 was investigated by Hitachi F-7100 Spectrofluorometer upon addition of selected metal ions such as $\mathrm{Li}^{+}, \mathrm{Na}^{+}, \mathrm{Ag}^{+}, \mathrm{Ca}^{2+}, \mathrm{Ba}^{2+}, \mathrm{Co}^{2+}, \mathrm{Cs}^{+}, \mathrm{Cu}^{2+}, \mathrm{Mg}^{2+}, \mathrm{Hg}^{2+}$, $\mathrm{Mn}^{2+}, \mathrm{Pb}^{2+}, \mathrm{Ni}^{2+}, \mathrm{Sr}^{2+}, \mathrm{Zn}^{2+}$ and $\mathrm{Al}^{3+}$. The reported Schiff base probes $(1 \mu \mathrm{M})$ showed a weak fluorescence emission spectrum at around $530 \mathrm{~nm}$ (for SK-1), $480 \mathrm{~nm}$ (for SK2), $508 \mathrm{~nm}$ (for SK-3), $518 \mathrm{~nm}$ (for MK-2), $430 \mathrm{~nm}$ (for MK-3) and $518 \mathrm{~nm}$ (for MK-4) with an excitation of 430 (for SK-1), $400 \mathrm{~nm}$ (for SK-2 and SK-3), $380 \mathrm{~nm}$ (for MK-3,) and $430 \mathrm{~nm}$ (for MK-2 and MK-4). Other metal ions $(10 \mu \mathrm{M})$ such as $\mathrm{Li}^{+}, \mathrm{Na}^{+}, \mathrm{Ag}^{+}, \mathrm{Ca}^{2+}, \mathrm{Ba}^{2+}, \mathrm{Co}^{2+}, \mathrm{Cs}^{+}$, $\mathrm{Cu}^{2+}, \mathrm{Mg}^{2+}, \mathrm{Hg}^{2+}, \mathrm{Mn}^{2+}, \mathrm{Pb}^{2+}, \mathrm{Ni}^{2+}, \mathrm{Sr}^{2+}$, and $\mathrm{Zn}^{2+}$ were added to the solution of Schiff base probes, considerable decrease or increase in fluorescent intensity of probes were not observed in Fig. 2. Whereas, upon addition of $\mathrm{Al}^{3+}(10 \mu \mathrm{M})$ remarkable fluorescence increase accompanied by a red shift of $24 \mathrm{~nm}$ from $530 \mathrm{~nm}$ to $554 \mathrm{~nm}$ was only noticed for the Schiff base probe SK-1 (Fig. 2a). Schiff base probe SK-1 exhibited a more than 37 -fold fluorescent enhancement alone in the presence of $\mathrm{Al}^{3+}$ ions. This increase in fluorescence intensity is such that the Schiff base probe SK-1 shows "OFF-ON" mode of high sensitivity for $\mathrm{Al}^{3+}$ ions. Furthermore, the Schiff base probe SK-1 indicated considerable color change from colorless to brilliant turquoise fluorescence in the presence of $\mathrm{Al}^{3+}$ ions under UV light, and this color change was also easily detected by
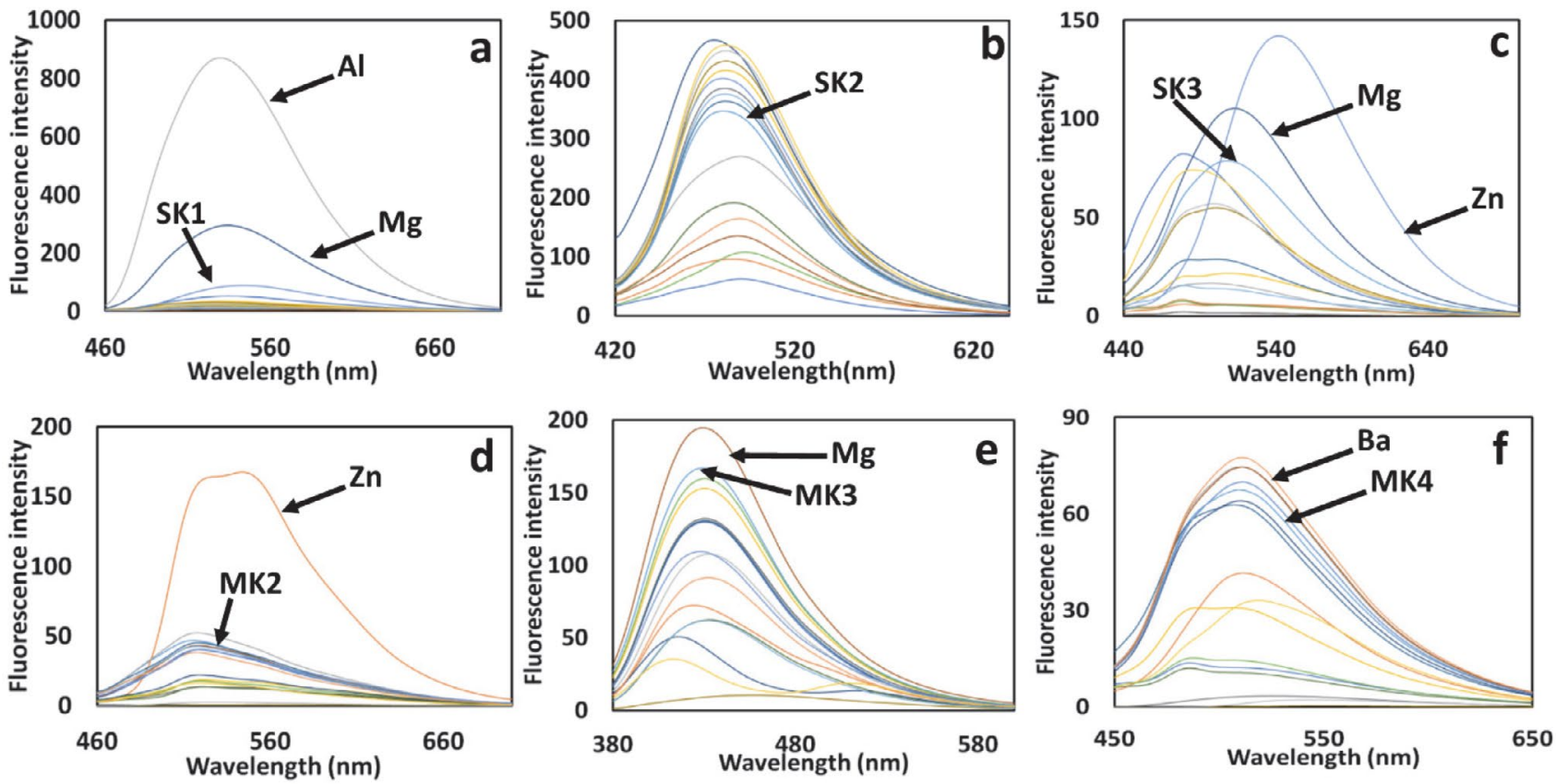

Fig. 2. Fluorescent emission spectra of $(1 \mu \mathrm{M})$; (a) SK-1, (b) SK-2, (c) SK-3, (d) MK-2, (e) MK-3, and (f) MK-4 in the presence of several metal ions such as $\mathrm{Li}^{+}, \mathrm{Na}^{+}, \mathrm{Ag}^{+}, \mathrm{Ca}^{2+}, \mathrm{Ba}^{2+}, \mathrm{Co}^{2+}, \mathrm{Cs}^{+}, \mathrm{Cu}^{2+}, \mathrm{Mg}^{2+}, \mathrm{Hg}^{2+}, \mathrm{Mn}^{2+}, \mathrm{Pb}^{2+}, \mathrm{Ni}^{2+}, \mathrm{Sr}^{2+}, \mathrm{Zn}^{2+}$ and $\mathrm{Al}^{3+}(10$ eq. for each metal ion). 


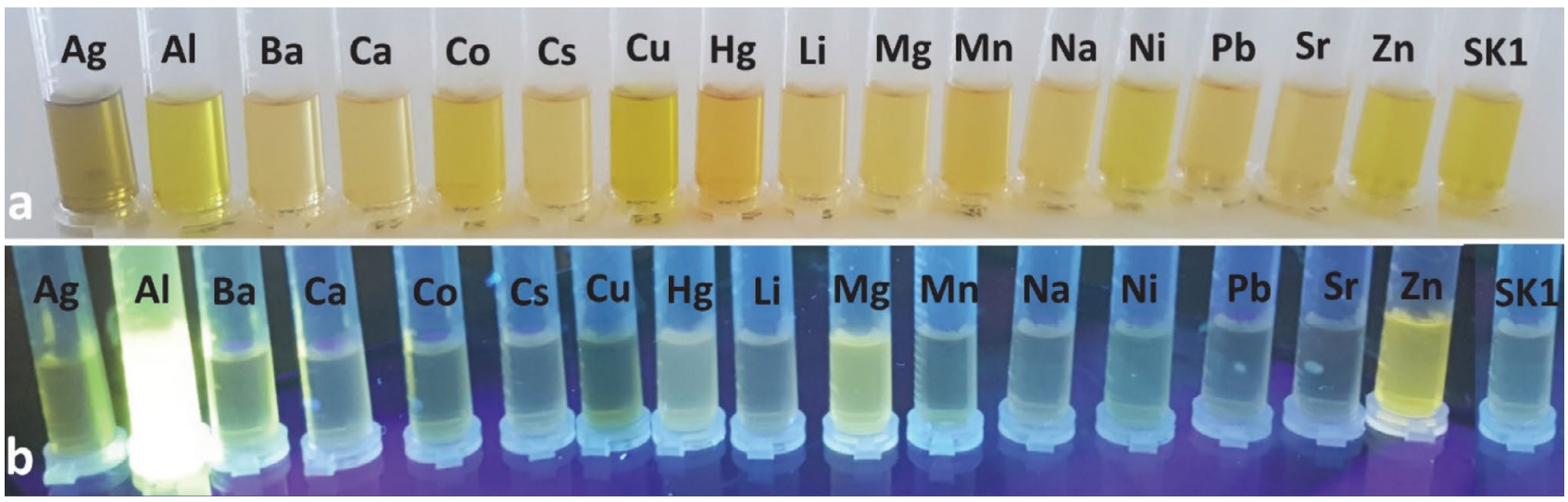

Fig. 3. Images showing the corresponding (a) visible color and (b) fluorescence color changes of SK-1 with and without metal cations (10 equiv. of $\mathrm{Li}^{+}, \mathrm{Na}^{+}, \mathrm{Ag}^{+}, \mathrm{Ca}^{2+}, \mathrm{Ba}^{2+}, \mathrm{Co}^{2+}, \mathrm{Cs}^{+}, \mathrm{Cu}^{2+}, \mathrm{Mg}^{2+}, \mathrm{Hg}^{2+}, \mathrm{Mn}^{2+}, \mathrm{Pb}^{2+}, \mathrm{Ni}^{2+}, \mathrm{Sr}^{2+}, \mathrm{Zn}^{2+}$ and $\mathrm{Al}^{3+}$ ) under day light and $\mathrm{UV}$ light.

the naked eye (Fig. 3). As a results, this Schiff base probe SK-1 can be evaluated to determine $\mathrm{Al}^{3+}$ ions in solution visually.

Photoinduced electron transfer (PET) mechanism includes the deactivation of the excited-state of fluorescent compounds by adding an electron to its frontier orbital. This electron addition to one of frontier orbital of excited-state causes a non-emissive state for fluorophore structures. For instance, the presence of one or more functional groups having free pair of electrons attached to the fluorescent molecule may quench its fluorescent intensity intramolecularly due to photoinduced electron transfer (PET) mechanism. However, a possible interaction of these electron donor groups with electron acceptor metal ions reduces efficient electron donor capabilities of these groups, thereby disconnecting the photoinduced electron transfer (PET) mechanism and increase the fluorescence output via chelation-enhanced fluorescence (CHEF). ${ }^{31,32}$ Herein, the emission intensity of SK-1 was very low because of the quenching by the lone pair electrons of imine group through a PET mechanism. However, with increasing of $\mathrm{Al}^{3+}(0-10$ equiv.), the fluorescence emission intensity of SK-1 $(1.0 \mu \mathrm{M})$ at $530 \mathrm{~nm}$ increased gradually (Fig. 4b). The complexation of the imine group $(-\mathrm{C}=\mathrm{N})$ with $\mathrm{Al}^{3+}$ ion given rise to the PET mechanism was suppressed, the fluorescence of the complex structure was restored. ${ }^{33,34}$

\section{3. Titration and Competition Studies}

The binding properties of SK-1 with $\mathrm{Al}^{3+}$ ions were studied by both UV-vis and fluorescent titration experiments (Fig. $4 \mathrm{a}$ and $4 \mathrm{~b}$ ). Firstly, we explored the UV-vis titration spectra of SK-1 with increasing concentrations of $\mathrm{Al}^{3+}$ in DMF. As shown in Fig. 4a, upon addition of increasing amounts of $\mathrm{Al}^{3+}$ ( 0.0 to 2.0 equiv.), absorption bands of SK-1 appeared at around $360 \mathrm{~nm}$ was gradually decreased with increasing amount of $\mathrm{Al}^{3+}$, while the intensities of absorption SK-1 at around $434 \mathrm{~nm}$ increased. Furthermore, the absorbance at around $434 \mathrm{~nm}$ reached maximum in the presence of 1.0 equiv. of $\mathrm{Al}^{3+}$ and showed nearly no change with further addition of metal ion. The titration configuration of SK-1 with $\mathrm{Al}^{3+}$ in Fig. 4a indicated 1 equiv. of $\mathrm{Al}^{3+}$ reacting with same equiv. of SK-1 could quickly reached an equilibrium, showing complex formation between SK-1 and $\mathrm{Al}^{3+}$ with 1:1 stoichiometry. To further examine the sensing properties of SK-1, sensitivity of SK-1 as a probe toward $\mathrm{Al}^{3+}$ ions was investigated by the fluorescence titration experiments by increasing concentration of $\mathrm{Al}^{3+}$ ions (0-10 equiv.) at $530 \mathrm{~nm}$ (Fig. 4b). Upon excitation at $430 \mathrm{~nm}$, SK-1 in the absence of any $\mathrm{Al}^{3+}$ showed practically no emission signal between the range of 460 and $700 \mathrm{~nm}$ which was probably due to PET process. ${ }^{35}$ However, a clear enhancement in fluorescence in-
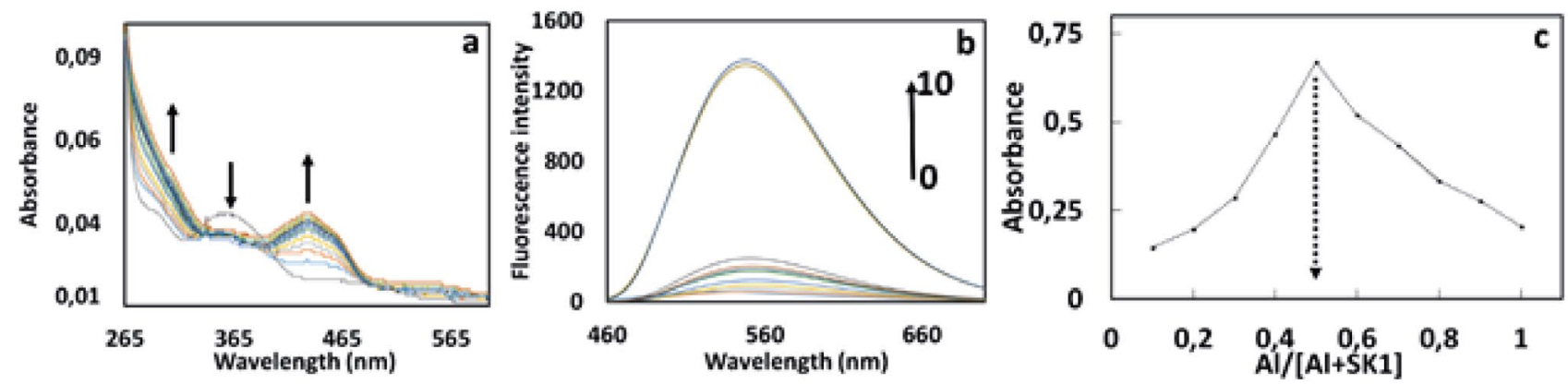

Fig. 4. (a) UV-Vis, (b) fluorescence titration spectra of compound SK-1 $(1 \mu \mathrm{M})$ respectively, upon addition of $\mathrm{Al}^{3+}$ (from 0 to 10 equiv.) at room temperature $\left(\lambda_{\mathrm{ex}}=430 \mathrm{~nm} ; \lambda_{\mathrm{em}}=530 \mathrm{~nm}\right)$ and (c) Job's plot for the determination of stoichiometry of SK-1-Al ${ }^{3+}$ system. 

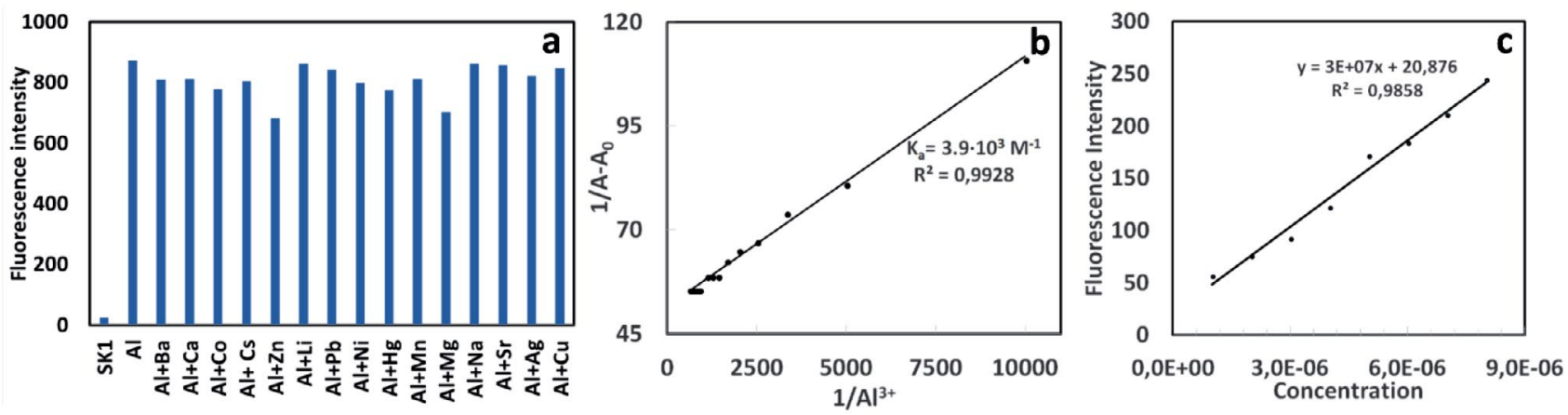

Fig. 5. Fluorescent selectivity of SK-1 $(1 \mu \mathrm{M})$ at $530 \mathrm{~nm}$ upon addition of various metal ions $(10 \mu \mathrm{M}) \mathrm{Li}^{+}, \mathrm{Na}^{+}, \mathrm{Ag}^{+}, \mathrm{Ca}^{2+}, \mathrm{Ba}^{2+}, \mathrm{Co}^{2+}, \mathrm{Cs}^{+}, \mathrm{Cu}^{2+}, \mathrm{Mg}^{2+}$, $\mathrm{Hg}^{2+}, \mathrm{Mn}^{2+}, \mathrm{Pb}^{2+}, \mathrm{Ni}^{2+}, \mathrm{Sr}^{2+}$, and $\mathrm{Zn}^{2+}, \lambda_{\text {ex }}=430 \mathrm{~nm}$. (b) Calculation of binding constant between $\mathbf{S K}-\mathbf{1}$ and $\mathrm{Al}^{3+}$. $\mathrm{A}_{0}$ is the absorbance of free SK-1 solution $(1 \mu \mathrm{M})$; $\mathrm{A}$ is the absorbance of compound SK-1 solution $(1 \mu \mathrm{M})$ upon addition of different amounts of $\mathrm{Al}^{3}$, (c) Calculation of detection limit of SK-1 for $\mathrm{Al}^{3+}$ with excitation at $430 \mathrm{~nm}$ and emission at $530 \mathrm{~nm}$ by addition of different amounts of $\mathrm{Al}^{3+}$ to SK-1 solution $(1 \mu \mathrm{M})$

tensity of SK-1 was observed gradually at around $530 \mathrm{~nm}$ with increasing concentrations of $\mathrm{Al}^{3+}$ as shown in Fig $4 \mathrm{~b}$. This increase in fluorescent intensity was probably due to the chelation-enhanced fluorescence (CHEF) effect that inhibiting the PET process by complexation of SK-1 with $\mathrm{Al}^{3+} \cdot{ }^{36}$ Furthermore, the detection limit of $\mathrm{Al}^{3+}$ was estimated based on the fluorescence titration profile (Fig. 5c). The detection limit of SK-1 in recognizing $\mathrm{Al}^{3+}$ was found to be $4.85 \cdot 10^{-7} \mathrm{M}$ which was lower than some reported literature results regarding $\mathrm{Al}^{3+}$ selective chemosensors. $^{37,38}$ This result was shown that this sensor could be used for both detection and monitoring of sub-micromolar concentration of aluminum ions in biological and environmental systems. To verify the practical application of SK-1 as an $\mathrm{Al}^{3+}$ selective and sensitive fluorescent sensor, competition experiments were also performed by adding of $\mathrm{Al}^{3+}$ into SK-1 solution mixed with other coexisting metal ions such as $\mathrm{Li}^{+}, \mathrm{Na}^{+}, \mathrm{Ag}^{+}, \mathrm{Ca}^{2+}, \mathrm{Ba}^{2+}, \mathrm{Co}^{2+}, \mathrm{Cs}^{+}$, $\mathrm{Cu}^{2+}, \mathrm{Mg}^{2+}, \mathrm{Hg}^{2+}, \mathrm{Mn}^{2+}, \mathrm{Pb}^{2+}, \mathrm{Ni}^{2+}, \mathrm{Sr}^{2+}$, and $\mathrm{Zn}^{2+}$. As de- picted in Fig. 5a, relatively low interference was seen for the detection of $\mathrm{Al}^{3+}$ in the presence of other competing metal ions. Although, the slightly decreasing in emission intensity of SK-1 at around $530 \mathrm{~nm}$ was observed in the presence of $\mathrm{Zn}^{2+}$, and $\mathrm{Mg}^{2+}$, fluorescent response was relatively detectable. However, upon addition of other competing metal ions under same conditions, it was seen that the fluorescence emission intensity at around $530 \mathrm{~nm}$ did not change considerably and SK-1 still have an efficient "turn-on" rate for the detection of $\mathrm{Al}^{3+}$. Consequently, it was concluded that SK-1 could be a promising selective and sensitive fluorescent sensor for the detection of $\mathrm{Al}^{3+}$ in the presence of competing metal ions.

\section{4. Binding Studies}

To determine the binding stoichiometry of SK-1 with $\mathrm{Al}^{3+}$, the method of continuous variations known as Job's plot was used. ${ }^{39}$ In this method, each experiment per-

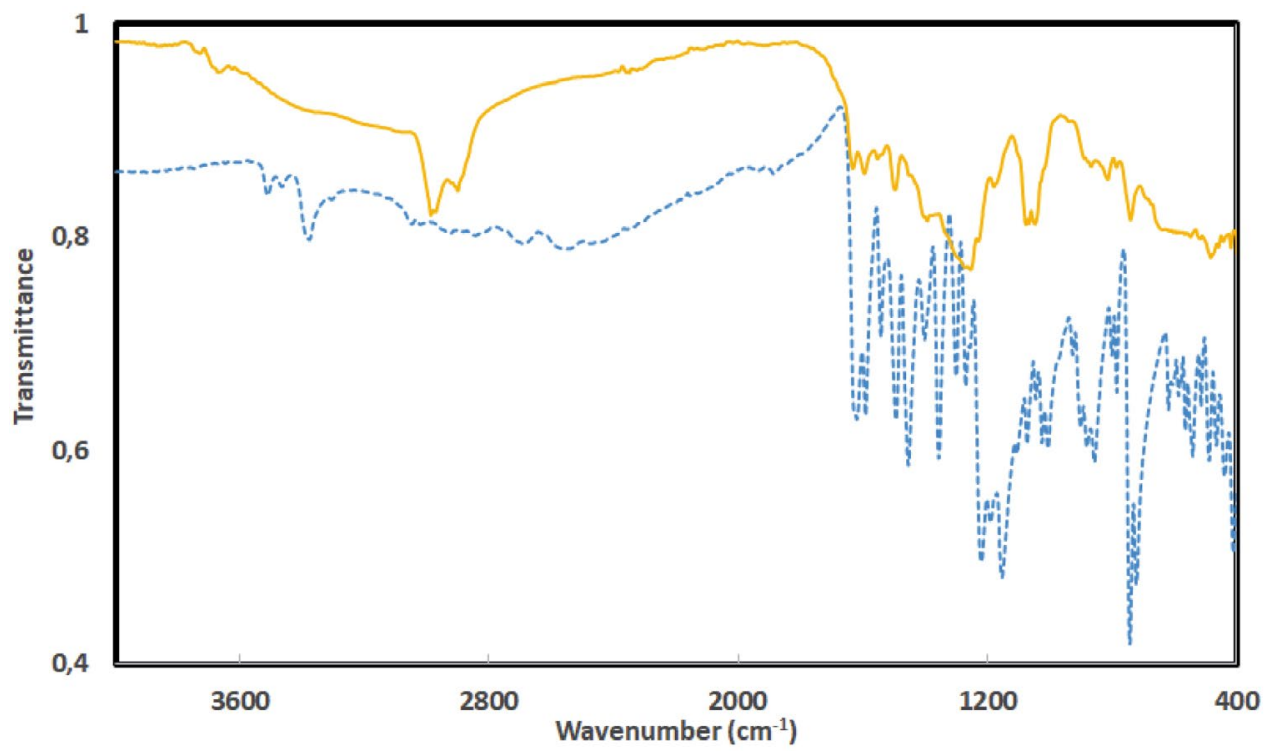

Fig. 6. The FT-IR (ATR) spectra of SK-1 with (1.0 equiv of $\mathrm{Al}^{3+}$ ) and without $\mathrm{Al}^{3+}$. 
formed with different concentrations of SK-1 and $\mathrm{Al}^{3+}$ with maintaining the total concentration at $10 \mu \mathrm{M}$. The plot obtained by measuring the fluorescence intensity at $530 \mathrm{~nm}$ for nine experiments with molar fraction of SK-1 (0.1 to $0.9)$. In this experiment, the maximum absorbance value was observed when the molar fraction was 0.5 (Fig. 4c) and it was consistent well with the UV-vis titration spectra (Fig. 4a). This data showed that 1 mole of SK-1 and $\mathrm{Al}^{3+}$ participated in the complex formation and binding mode was determined as 1:1 stoichiometry. Furthermore, the binding constant of the probe SK-1 with $\mathrm{Al}^{3+}$ were calculated by the Benesi-Hildebrand method. ${ }^{40}$ From curve fitting of absorbance values of probe SK-1 against the reciprocal of the $\mathrm{Al}^{3+}$ concentration, this plot yielded a linear fit as seen in Fig. 5b. The value of the binding constant was calculated as $3.9 \cdot 10^{3} \mathrm{M}^{-1}$ which was within the range of those $\left(10^{3}-10^{9}\right.$ $\mathrm{M}^{-1}$ ) previously reported $\mathrm{Al}^{3+}$ sensors. ${ }^{41}$ In addition, the linear plot also proved the 1:1 complexation behavior of SK-1 to $\mathrm{Al}^{3+}$. Because, if a 1:1 metal-probe complex is formed between receptor and metal ions, Benesi-Hildebrand plot should be linear. ${ }^{42}$ In related to stoichiometry, the binding site participated in complexation was clarified by FT-IR (ATR) and ${ }^{1} \mathrm{H}$ NMR experiments along with stoichiometry confirmation as presented in Fig. 6 and 7.

The IR spectra of free SK-1 and SK-1-Al ${ }^{3+}$ complex structure showed that the characteristics frequencies of SK-1 with 1.0 equiv. of $\mathrm{Al}^{3+}$ exhibited significant changes as compared with those of free the SK-1 (Fig. 6). The IR spectra of the free SK-1 showed the absence of bands at around 1735 and $3300 \mathrm{~cm}^{-1}$ attributable to the carbonyl $v(\mathrm{C}=\mathrm{O})$ and $v\left(\mathrm{NH}_{2}\right)$ stretching vibrations and a clear strong new band at around $1616 \mathrm{~cm}^{-1}$ due to azomethine $v(\mathrm{HC}=\mathrm{N})$ linkage. ${ }^{4-45}$ All these existing and disappearing signals in IR indicated that amino and aldehyde groups in starting reactants (Scheme 1) were converted into the SK-1 and synthesis of the SK-1 was successfully carried out. The comparison of IR spectra of free SK-1 and its $\mathrm{Al}^{3+}$ complex (Fig. 6) demonstrated that SK-1 probe was principally coordinated to the $\mathrm{Al}^{3+}$ ion. The strong band appearing at around $1616 \mathrm{~cm}^{-1}$ due to azomethine group shifted to a higher frequency at $1629 \mathrm{~cm}^{-1}$ in $\mathrm{Al}^{3+}$ complex, indicating participation of azomethine group in the complexation with the $\mathrm{Al}^{3+}$ ion. On the other hand, the free $\mathrm{OH}$ group at $3378 \mathrm{~cm}^{-1}$ was completely disappeared at 1 equiv. of $\mathrm{Al}^{3+}$. In addition, disappearing of strong band at around $3378 \mathrm{~cm}^{-1}$ indicated that phenolic hydroxy group of SK-1 participated in the complex formation with $\mathrm{Al}^{3+}$.
To better understand the complexation between the probe SK-1 and $\mathrm{Al}^{3+},{ }^{1} \mathrm{H}$ NMR experiment of SK-1 in DMSO- $d_{6}$ were examined by addition of 1 equiv. of $\mathrm{Al}^{3+}$. As seen in Fig. 7, three phenolic - $\mathrm{OH}$ signals belonging to SK-1 was observed at around 9.88, 9.02 and $14.21 \mathrm{ppm}$. Compared the phenolic -OH signals, appearing signal at around $14.21 \mathrm{ppm}$ attributed the ortho position of SK-1 is probably due to the intramolecular hydrogen bonding (Fig. 7). While the phenolic $\mathrm{OH}$ proton at $14.21 \mathrm{ppm}$ disappeared when added of 1.0 equiv. of $\mathrm{Al}^{3+}$ to SK-1 solution, the other signal at around 9.88 and $9.02 \mathrm{ppm}$ shifted to downfield. Also, it was seen that the imine $(\mathrm{CH}=\mathrm{N})$ proton of SK-1 at $8.91 \mathrm{ppm}$ was slightly shifted to some extent. This shift for the imine proton was probably due to complexation ability of the azomethine group after coordination of SK-1 with $\mathrm{Al}^{3+} .{ }^{44}$ All these shifting and/or disappearing of signals showed that both phenolic $\mathrm{OH}$ group located in ortho position and imine group of SK-1 were efficient on complex formation between SK-1 and $\mathrm{Al}^{3+}$. In the light of obtained spectroscopic data, possible complex formation mechanism was given in Fig. 8.
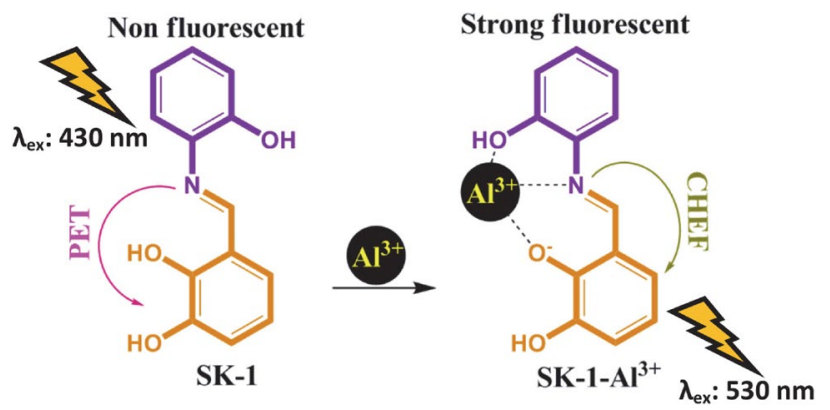

Fig. 8. Proposed binding mechanism between the compound SK-1 and $\mathrm{Al}^{3+}$.

\section{5. Biological Applications}

SK-1 was successfully applied for imaging of $\mathrm{Al}^{3+}$ ions in human breast cancer cells, MCF7 under fluorescence microscope. Cells treated with free SK-1 were used as controls. When MCF7 cells were incubated with SK-1 $(10 \mu \mathrm{M})$, it was not seen any fluorescence response (Fig. 9e). However, after addition of $\mathrm{Al}^{3+}$ ions, a brilliant red fluorescence was sighted in the MCF7 cells (Fig. 9b). Merged images of fluorescence and bright-field showed that fluorescence signals were detected in the intra-cel-

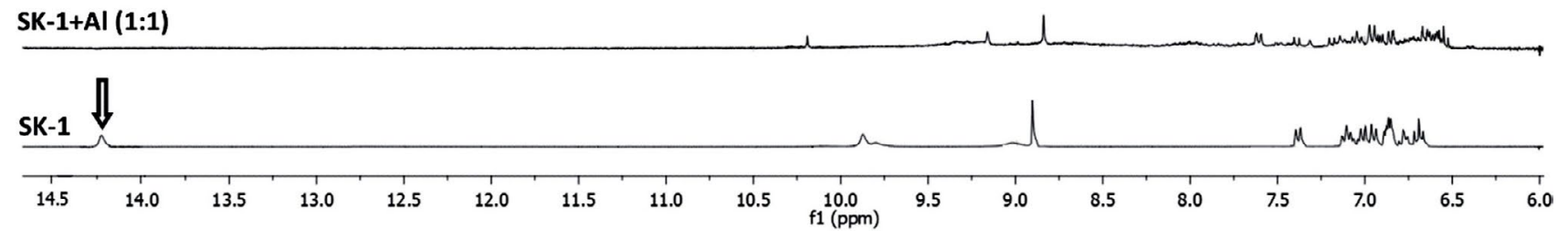

Fig. 7. ${ }^{1} \mathrm{H}$ NMR spectra in DMSO- $d_{6}$ of SK-1 with (1.0 equiv of $\left.\mathrm{Al}^{3+}\right)$ and without $\mathrm{Al}^{3+}$. 


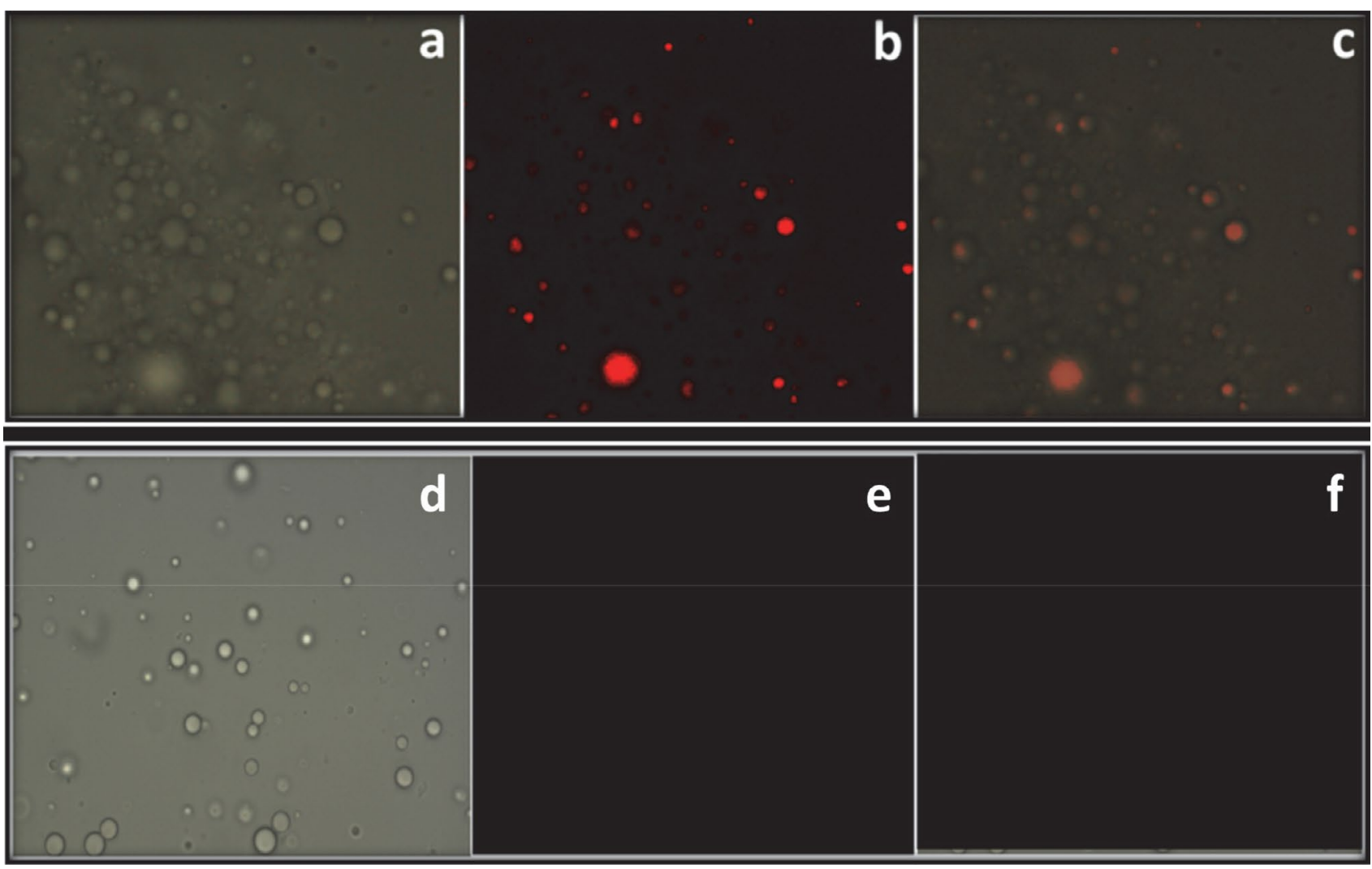

Fig. 9. Fluorescence images of $\mathrm{Al}^{3+}$ using probe SK-1 in MCF7: (a) bright field image of MCF7 cells treated with probe SK-1; (b) fluorescence image of MCF7 cells treated with probe SK-1; (c) merged image of (a) and (b); (d) bright field image of MCF7 cells treated with probe SK-1 without Al ${ }^{3+}$; (e) fluorescence image of MCF7 cells treated with probe SK-1 without $\mathrm{Al}^{3+}$; (d); (f) merged image of (d) and (e).

lular zone, showing the distribution of $\mathrm{Al}^{3+}$ and cell membrane permeabilities of SK-1 molecules (Fig 9c). On the other hand, Fig. 9 indicated that SK-1 could stain $\mathrm{Al}^{3+}$ ions in living cells without any harm (cells remain alive even after several hours of exposure to $10 \mu \mathrm{M}$ of SK-1), making it useful to monitor $\mathrm{Al}^{3+}$ in biological systems.

\section{Conclusion}

In conclusion, visual detection of highly selective and sensitive $\mathrm{Al}^{3+}$ ions by a very simple and low-cost fluorescence sensor (SK-1) based on the blocking PET process was carried out successfully. SK-1 showed high sensitivity with the detection limit at around $4.8 \times 10^{-7} \mathrm{M}$ in the micromolar scale and selectivity response towards $\mathrm{Al}^{3+}$ over other metal ions with 37-fold fluorescence enhancement. The predicted configuration of the SK-1-Al ${ }^{3+}$ complex formation was well-characterized to be 1:1 by spectroscopic analyses. Beyond that, SK-1 was utilized to detect sensitively the $\mathrm{Al}^{3+}$ ions in living cells by emitting visible fluorescence. Cell applications indicated that SK-1 could be used as an excellent fluorescence probe for visualizing of $\mathrm{Al}^{3+}$ ions in cell lines.

\section{Acknowledgments}

The authors declare that there is no conflict of interest. This study is part of master thesis of Sedat Keskin and authors of this paper gratefully would like to thank Karamanoglu Mehmetbey University Research Foundation (BAP) and The Scientific and Technological Research Application Center (BILTEM) for the financial and technical supports.

\section{References}

1. J. Zhu, Y. Zhang, L. Wang, T. Sun, M. Wang, Y. Wang, D. Ma, Q. Yang, Y. Tang. Tetrahedron Lett., 2016, 57, 3535-3539.

DOI:10.1016/j.tetlet.2016.06.112

2. X. Yan, H. Yang, F. Tian. RSC Adv., 2015, 107012-107019. DOI:10.1039/C5RA17557G

3. V. K. Gupta, S. K. Shoora, L. K. Kumawat, A. K. Jain. Sensors Actuators, B Chem., 2015, 209, 15-24.

DOI:10.1016/j.snb.2014.10.143

4. K. Kaur, V. K. Bhardwaj, N. Kaur, N. Singh. Inorg. Chem. Commun., 2012, 18, 79-82. DOI:10.1016/j.inoche.2012.01.018

5. Y. Xu, S. Mao, H. Peng, F. Wang, H. Zhang, S.O. Aderinto, H. Wu. J. Lumin., 2017, 192, 56-63.

DOI:10.1016/j.jlumin.2017.06.023 
6. L. Kang, Y. T. Liu, N.N. Li, Q. X. Dang, Z. Y. Xing, J. L. Li, Y. Zhang. J. Lumin., 2017, 186, 48-52.

DOI:10.1016/j.jlumin.2016.12.056

7. T. Han, X. Feng, B. Tong, J. Shi, L. Chen, J. Zhi, Y. Dong. Chem. Commun., 2012, 48, 416-418. DOI:10.1039/C1CC15681K

8. M. H. Nagaoka, T. Maitani. Analyst, 2000, 125, 1962-1965. DOI: $10.1039 / b 006590 k$

9. M. Shellaiah, Y. H. Wu, H. C. Lin. Analyst, 2013, 138, 29312942. DOI:10.1039/c3an36840h

10. S. Mukherjee, P. Mal, H. Stoeckli-Evans. J. Lumin., 2016, 172, 124-130. DOI:10.1016/j.jlumin.2015.11.014

11. S. Das, D. Karak, S. Lohar, A. Banerjee, A. Sahana, D. Das. Anal. Methods., 2012, 4, 3620-3624.

DOI:10.1039/c2ay25825k

12. X. Sun, Y.-W. Wang, Y. Peng. Org. Lett., 2012, 14, 3420-3423. DOI:10.1021/ol301390g

13. C.-Y. Huang, Y. Jhong, J.-L. Chir, A.-T. Wu. J. Fluoresc., 2014, 24, 991-994. DOI:10.1007/s10895-014-1404-1

14. H. Cheng, Y. Qian. RSC Adv., 2015, 5, 82887-82893. DOI:10.1039/C5RA15546K

15. M. Shellaiah, Y.C. Rajan, P. Balu, A. Murugan. New J. Chem., 2015, 39, 2523-2531. DOI:10.1039/C4NJ02367F

16. S. Jana, S. Dalapati, N. Guchhait. J. Phys. Chem. A, 2013, 117, 4367-4376. DOI:10.1021/jp3120463

17. G. Q. Wang, J. C. Qin, L. Fan, C. R. Li, Z. Y. Yang. J. Photochem. Photobiol. A Chem., 2016, 314, 29-34.

DOI:10.1016/j.jphotochem.2015.08.005

18. L. Wang, W. Qin, X. Tang, W. Dou, W. Liu. J. Phys. Chem. A., 2011, 115, 1609-1616. DOI:10.1021/jp110305k

19. J. Shao, H. Lin, Z.-S. Cai, H. Lin. J. Photochem. Photobiol. B Biol., 2009, 95, 1-5. DOI:10.1016/j.jphotobiol.2008.12.007

20. J. Kumar, M.J. Sarma, P. Phukan, D. K. Das. Dalt. Trans., 2015, 44, 4576-4581. DOI:10.1039/C4DT03932G

21. J. Wu, W. Liu, J. Ge, H. Zhang, P. Wang. Chem. Soc. Rev., 2011, 40, 3483-3495. DOI:10.1039/c0cs00224k

22. T. Gunnlaugsson, H. D. P. Ali, M. Glynn, P. E. Kruger, G. M. Hussey, F. M. Pfeffer, C. M. G. Dos Santos, J. Tierney. J. Fluoresc., 2005, 15, 287-299.

DOI:10.1007/s10895-005-2627-y

23. M. H. Yan, T. R. Li, Z. Y. Yang. Inorg. Chem. Commun., 2011, 14, 463-465. DOI:10.1016/j.inoche.2010.12.027

24. S. Sen, T. Mukherjee, B. Chattopadhyay, A. Moirangthem, A. Basu, J. Marek, P. Chattopadhyay. Analyst, 2012, 137, 39753981. DOI:10.1039/c2an35560d

25. C. Dohno, A. Okamoto, I. Saito. J. Am. Chem. Soc., 2005, 127, 16681-16684. DOI:10.1021/ja054618q

26. L. Fan, T. R. Li, B. D. Wang, Z. Y. Yang, C. J. Liu. Spectrochim. Acta - Part A Mol. Biomol. Spectrosc., 2014, 118, 760-764. DOI:10.1016/j.saa.2013.09.062
27. Y. J. Lee, C. Lim, H. Suh, E. J. Song, C. Kim. Sensors Actuators B Chem., 2014, 201, 535-544. DOI:10.1016/j.snb.2014.05.035

28. S. Guha, S. Lohar, A. Sahana, A. Banerjee, D. A. Safin, M. G. Babashkina, M.P. Mitoraj, M. Bolte, Y. Garcia, S.K. Mukhopadhyay, D. Das. Dalt. Trans., 2013, 42, 10198-10207. DOI:10.1039/c3dt51045j

29. S. K. Shoora, A. K. Jain, V. K. Gupta. Sensors Actuators, B Chem., 2015, 216, 86-104. DOI:10.1016/j.snb.2015.04.038

30. M. Tajbakhsh, G. B. Chalmardi, A. Bekhradnia, R. Hosseinzadeh, N. Hasani, M. A. Amiri. Spectrochim. Acta Part A Mol. Biomol. Spectrosc., 2018, 189, 22-31.

DOI:10.1016/j.saa.2017.08.007

31. P. Alaei, S. Rouhani, K. Gharanjig, J. Ghasemi. Spectrochim. Acta - Part A Mol. Biomol. Spectrosc., 2012, 90, 85-92. DOI:10.1016/j.saa.2012.01.008

32. N. C. Lim, S. V. Pavlova, C. Brückner. Inorg. Chem., 2009, 48, 1173-1182. DOI:10.1021/ic801322x

33. J. M. An, Z. Y. Yang, M. H. Yan, T. R. Li. J. Lumin., 2013, 139, 79-83. DOI:10.1016/j.jlumin.2013.02.019

34. T. Gunnlaugsson, A. P. Davis, J. E. O’Brien, M. Glynn. Org. Lett., 2002, 4, 2449-2452. DOI:10.1021/ol0260041

35. G. Zhu, Y. Wang, H. Fu, X. Xu, Z. Cui, X. Ji, G. Wu. Spectrochim. Acta Part A Mol. Biomol. Spectrosc., 2015, 137, 148153. DOI:10.1016/j.saa.2014.08.021

36. F. Karagöz, O. Güney, M. Kandaz, A.T. Bilgiçli. J. Lumin., 2012, 132, 2736-2740. DOI:10.1016/j.jlumin.2012.05.005

37. D. Zhou, C. Sun, C. Chen, X. Cui, W. Li. J. Mol. Struct., 2015, 1079, 315-320. DOI:10.1016/j.molstruc.2014.09.050

38. W.-H. Ding, D. Wang, X.-J. Zheng, W.-J. Ding, J.-Q. Zheng, W.-H. Mu, W. Cao, L.-P. Jin. Sensors Actuators B Chem., 2015, 209, 359-367. DOI:10.1016/j.snb.2014.11.144

39. J. S. Renny, L. L. Tomasevich, E. H. Tallmadge, D. B. Collum. Angew. Chem. Int. Ed. Engl., 2013, 52, 11998-2013.

DOI:10.1002/anie.201304157

40. H. A. Benesi, J. H. Hildebrand. J. Am. Chem. Soc., 1949, 71, 2703-2707. DOI:10.1021/ja01176a030

41. C. Kim, T. G. Jo, J. Lee, E. Nam, K. H. Bok, M.H. Lim. New J. Chem., 2016, 40, 8918-8927. DOI:10.1039/C6NJ01544A

42. H. M. Kim, C. Jung, B. R. Kim, S.-Y. Jung, J. H. Hong, Y.-G. Ko, K. J. Lee, B. R. Cho. Angew. Chemie Int. Ed., 2007, 46, 3460-3463. DOI:10.1002/anie.200700169

43. İ. Kaya, E. Kartal, D. Şenol. Des. Monomers Polym., 2015, 18, 524-535. DOI:10.1080/15685551.2015.1041084

44. V. K. Gupta, A. Kumar, S. Lokesh, K.Kumawat. Sensors Actuators, B Chem., 2015, 195, 98-108.

DOI:10.1016/j.snb.2013.12.092

45. V. K. Gupta, B. Sethi, R. A. Sharma, S. Agarwal, A. Bhartia. j. Mol. Liq., 2013, 177, 114-118.

DOI:10.1016/j.molliq.2012.10.008 


\section{Povzetek}

Za detekcijo aluminijevih ionov na osnovi fotoinduciranega prenosa elektronov smo sintetizirali in okarakterizirali šest Schiffovih baz. $Z$ absorpcijskimi in emisijskimi spektri smo raziskovali možnost vezave sintetiziranih spojin $\mathrm{z}$ različnimi kovinskimi kationi. S spektrofotometrijo smo ugotovili, da daje spojina SK-1 odličen fluorescenčni odziv na ciljne aluminijeve ione. Razlog je verjetno njena kelatna struktura. Spojina SK-1 je za aluminijeve ione pokazala večjo občutljivost in selektivnost kot za ostale ione. Rezultati raziskav možnosti uporabe SK-1 za detekcijo aluminijevih ionov v celicah so pokazali, da je lahko fluorescenčni senzor SK-1 obetavna sonda za določanje in/ali monitoring aluminijevih ionov v bioloških in/ali kemijskih vzorcih. 